Article

\title{
Sustainability Value Creation, Survival, and Growth of the Company: A Critical Perspective in the Sustainability Balanced Scorecard (SBSC)
}

\author{
Ivo Hristov *(D), Antonio Chirico ${ }^{(\mathbb{C}}$ and Andrea Appolloni $(\mathbb{D}$ \\ Department of Management and Law, University of Rome Tor Vergata, 00133 Rome, Italy; \\ chirico@economia.uniroma2.it; (A.C.); andrea.appolloni@uniroma2.it (A.A.) \\ * Correspondence: hristov@economia.uniroma2.it; Tel.: +39-06-7259-5751
}

Received: 24 February 2019; Accepted: 4 April 2019; Published: 10 April 2019

check for updates

\begin{abstract}
The issue of sustainability in company strategy has assumed crucial relevance in recent years. Many companies have implemented specific environmental and sustainability management systems such as the Sustainability Balanced Scorecard (SBSC), which integrates sustainability and the traditional Balanced Scorecard (BSC). However, environmental and sustainability aspects are often not linked to economic success, and qualitative analysis is not considered adequately by managers. Therefore, these dimensions remain unclear, because it is necessary to analyze the conditions under which the SBSC represents a suitable tool for sustainability value creation in more depth. In this context, the purpose of the study is to propose a new strategic framework to provide a way to manage critical issues connected to the SBSC. Thanks to the information obtained from a survey and interviews conducted with managers of Italian companies, we created an adjusted SBSC (ASBSC) that allows us to consider the critical aspects from a new perspective, named the critical perspective. The conceptual model is developed in five dimensions (conceptual, structural, environmental, social, and economic). Research findings suggest that considering the critical perspective makes it possible to build the ASBSC in order to achieve sustainability and economic success of the company. The proposed framework contributes to the existing literature on improving the performance of the SBSC.
\end{abstract}

Keywords: balanced scorecard; SBSC; sustainability; critical perspective; ASBSC

\section{Introduction}

The growth and value creation of a company depend on interactions and combinations of several circumstances, including the capabilities of its management, the development and use of its intellectual capital (IC), its financial assets, its investment in research and development (R\&D) and innovation, and its sector and geographical location. Economic dimensions are more easily evaluated by clearly expressed quantitative indicators, but environmental and sustainability measurement requires a balance between quantitative and qualitative indicators. Specific environmental and sustainability management systems have been implemented in recent years by companies [1]. These systems, however, have rarely been integrated with the general management system of a company. As a consequence, environmental concerns and sustainability are often not linked to the economic success of the company, and the economic contribution of environmental and sustainability management therefore remains unclear.

In this context, the Balanced Scorecard (BSC) is a popular methodology to integrate financial and nonfinancial aspects with the general management of a company [1]. The BSC assists in the identification and management of improvements in financial and nonfinancial business goals simultaneously. Since the BSC was introduced, many authors have proposed some modifications and 
improvement to adapt the traditional BSC to others scorecards that were specific for different areas or industrial environments [2]. Both academics [3] and practitioners consider the BSC an appropriate tool to account for sustainability issues. The BSC as a strategic management tool is intended to identify the major strategically relevant issues of a business and to describe and depict the causal contributions of issues that contribute to the achievement of a company's strategy [4]. The use of the sustainability indicators and qualitative analysis could contribute to the survival and growth of a company in the long term, improving its performance [5-8]. According to Brown (1998), if an "institution survives over the long term, one might conclude that it has become sustainable." Therefore, sustainability value creation, survival, and growth have assumed enormous relevance in the last 30 years.

Modifications to the original BSC that explicitly consider environmental and social issues are often referred to as the Sustainability Balanced Scorecard (SBSC) [7]. The SBSC fulfills the central requirement of the sustainability concept for permanent improvement of business performance [1,3,9-13]. In particular, SBSC implementation helps to identify the important strategic environmental and social goals of the company [14]. Study results prove that the number of companies that are oriented toward implementing the BSC has increased in recent years, but implementation still encounters limits. In presenting their review on the SBSC, Hansen and Schaltegger [7] highlight that the structure of the SBSC characterizes the maturity of the value system of a company as well as its sustainability strategy. This assumption is based on the hypothesis that the BSC represents a very useful tool for managing and addressing sustainability issues. According to Hahn and Figge [15], this remains unsubstantiated, because is necessary to analyze in more depth the conditions under which the BSC represents a suitable tool to achieve and manage sustainability. One strength of the SBSC lies in its ability to bridge the gap between the strategic and operative level identifying those environmental and social aspects which are necessary for securing a company's financial success $[16,17]$. A broad consensus has been established that the SBSC is one of the most effective tools in evaluating potential investments and initiatives by better integration of the environmental, social and economic aspects of sustainability measurement and management [18-22].

In order to use the BSC as a tool to improve company performance and sustainability management, it is necessary to understand under which circumstances it can be used for such a purpose and to achieve and manage sustainability issues [17]. In order to contribute to the literature regarding these fundamental aspects, this paper has two goals: (1) to identify the problems connected to the structure of the BSC considering sustainability and social aspects, and (2) to identify ways to consider and overcome these problems, providing practitioners with a tool to achieve sustainability value creation and scholars with an opportunity to further their research. In this regard, we analyzed the critical aspects connected to the traditional BSC and the SBSC by reviewing the most relevant literature and using information from two data sources, a survey and interviews. We discussed with managers of Italian companies the critical aspects identified and ways to overcome the problems based on their daily experience with managing with this tool.

In particular, we identified a new perspective called the critical perspective that allows us to consider and contain the limitations during the implementation and use of the SBSC. Only by considering more deeply the relevance of the structure, concept, qualitative analysis, and social and economic dimensions during the construction process of the SBSC will it be possible to adapt the traditional structure of the BSC to the SBSC.

In the next sections, we briefly summarize the prior research findings, then we describe our research methods and discuss the results. We finally draw main conclusions from this work to propose potential avenues for the research agenda within this field.

\section{Sustainability Balanced Scorecard (SBSC)}

In the literature, CSR can be defined as a "business approach that creates and sustains the long-term value of a company by embracing opportunities and managing risks from three dimensions: the economic, environmental, and social perspective" [23-26]. Social sustainability is quite common 
in CSR in the context of concerns for companies to develop strong and sustainable relationships with customers, employees, suppliers, stakeholders, and last but not least, the social enterprise community. In particular, in order to ensure their longevity, these processes need to be continuously measured and evaluated through periodic qualitative and quantitative indicators [8]. Sustainability "refers to firm engagement with social and environmental issues in additional to their economic activities" [27]. In other words, while CSR "recognizes that corporate growth and profitability are important, it also requires the corporation to pursue societal goals, specifically those relating to sustainable development environmental protection, social justice and equity, and economic development" [28]. In fact, most existing measurement systems do not fully address the qualitative perspective. In this context, the development and use of qualitative analysis provides an important lever for the implementation of sustainability management. To this end, the BSC is a widely used strategic management tool for performance measurement in which financial and nonfinancial indicators are integrated with corporate visions.

The BSC aims to remedy the limitations of traditional monitoring models, as well as translate competitive strategies into key performance indicators (KPIs), to ensure a balance between short-term performance, measured through financial parameters, and nonfinancial factors that should lead the company to superior competitive performance and sustainability over time [4,29-33]. Malmi's [34] study revealed five reasons behind an organization's decision to adopt the BSC: (a) to translate strategy into action, (b) to manage quality programs, (c) to support change agendas, (d) to follow managerial fads and fashions, and (e) to abandon traditional budgeting. For instance, from Malina and Selto's [30] study, one can learn that the BSC presents significant opportunities to develop, communicate, and implement strategy, which confirms Kaplan and Norton's [4] arguments for linking BSC measures to the organizational strategy map. Malina and Selto's [30] results further demonstrate the causal relationship between effective management control, motivation, strategic alignment, and beneficial effects of the BSC [35]. In the literature, several studies have applied the BSC to fields including manufacturing, finance, human resources, supply chain management, and marketing, in order to reach effective and efficient improvement of an organization [8,36-38]. Several studies on the BSC have also involved a sustainability approach in order to implement performance evaluation and reach maximum benefit for decision-making approaches. Thanks to these considerations, researchers have developed extended scorecard designs under the name of SBSC [1,7], sustainability scorecard (SIGMA, 2003), or responsive business scorecard [16]. Performance management systems such as the SBSC can be studied with regard to their design, implementation, use, and evolution $[10,39,40]$. Scholars have emphasized the potential of the SBSC for integrating conventional strategic management with CSR [1]. In particular, this integration allows management to achieve goals in all dimensions of sustainability by integrating economic, environmental, and social issues. In addition, the SBSC integrates these three dimensions into a single management system instead of requiring parallel systems. Several scholars proposed applications of the SBSC. Elijido [14] provided an empirical study on the Australia's largest publicly listed companies. Dias-Sadinha and Reijnders [23] evaluate social and environmental performance in their study of 13 Portuguese firms. Similar applications of SBSC can be found in Moller and Schalteggar [24] and Sidiropoulos et al. [25], where an environmental perspective is added to the traditional BSC. Giannoukou and Beneki [41] proposed a conceptual framework based on SBSC in the field of tourism.

For example, Kongar [38] proposed a green BSC approach combined with linear physical programming (LPP) to measure the performance of supply chain management while defining the appropriate measurement criteria. In the same way, Tsai et al. [42] utilized the SBSC as a multicriteria framework for socially responsible investment evaluation. Hsu et al. [43] utilized the fuzzy Delphi method to construct an SBSC framework to evaluate sustainable performance of the semiconductor industry in Taiwan. Epstein and Wisner [3] assert that SBSC can be used to communicate the importance of a company's sustainability strategy thereby helping senior managers to reposition and improve their sustainability performance and corporate image. 
At the same time, different structures were proposed by the scholars. In particular, Hansen and Schaltegger [7] distinguish three types of architectures: hierarchical, semi-hierarchical, and non-hierarchical of SBSC. Marrewijk [44] established that companies which adopt a strictly hierarchical SBSC structure tend to have a more strongly profit-driven value system that is motivated by pragmatic profit maximization. Lin et al. [45] and Nikolaou and Tsalis [46] proposed a modified SBSC for sustainable development. Figge [1] highlights the relevance of the traditional BSC's structure. The fact that all business activities are integrated with and linked to the successful implementation of the business strategy can be used for management. According to the author, in order to formulate the SBSC, the process can be divided into three steps. First of all, is necessary to identify the relevant strategic business units and ways to implement and integrate different levels inside the company (integration). Then it is necessary to identify and analyze the environmental and social exposure of the business unit (sustainability/environment). Finally, the core of the structure is the determination of the strategic relevance of environmental and sustainability aspects (strategy). Only by considering these relevant aspects step-by-step is it possible to adapt the structure of the BSC to the SBSC. According to the author, one possible solution is to consider these steps in a new perspective, called nonmarket perspective, in addition to the other perspectives. Therefore, as a tool for the strategic management of CSR, the SBSC is supposed to assist companies "to move towards a more sustainable performance" [6].

Hence, as a primary condition for its effectiveness in CSR management, the SBSC needs to directly induce positive contributions to desirable economic, environmental, and social outcomes going beyond financial outcomes at the organizational level. Nevertheless, in the literature several authors talk about the difficulty in considering qualitative analysis by managers and highlight different critical aspects.

\section{Criticism of BSC and SBSC}

The BSC provides a foundation for successful strategies and effectively managing change in a company [47]. It is a strategic tool that aims to clarify strategy and translate it into action. While financial measures have been in wide use for many years, new frameworks have emerged that extend organizational perspectives beyond traditional financial measures. In addition, many scholars have highlighted the potentially beneficial role of the BSC for CSR $[1,7,8,48,49]$. In particular, according to Duman [8], it promises to balance quantitative and qualitative goals, which may bring more attention to environmental and social issues in companies. In the BSC all relevant aspects for achieving a permanent competitive advantage should be included. The BSC assists the management in all three dimensions of sustainability (economic, environmental, and social) simultaneously. Therefore, the relation between all three performance dimensions of sustainability has to be explicitly taken into account in an integrative way. This could help to avoid sustainability issues being entirely overlooked by managers and companies through aspects that are strategically relevant for financial success and help to create a shared understanding of why certain sustainability aspects are strategically relevant by linking these through cause-and-effect chains toward financial outcomes.

While this is undoubtedly correct, it often involves significant changes to organizations, therefore new corporate policies, strategies, and procedures are introduced. These changes can be problematic, but at same time they are essential for survival and growth. We critically reflect on the desire to make the SBSC as a vehicle for organizational change and to connect it with systems-level sustainability indicators. Conceptually, the BSC aims to translate strategy into action by formulating and defining the goals and measures based on the top down strategy from the financial perspective through the other perspectives. To this end, it is necessary to focus firstly on the traditional structure and concept of the BSC. By only analyzing the problems related to these two dimensions, in addition to the sustainability, it will be possible to adapt the BSC to the sustainability issues. In this context, considering that sustainability management in strategy implementation contributes to economic objectives helps to disseminate the idea of sustainable development in business, as it serves as an appropriate model for other businesses [1]. According to the Organization for Economic Co-operation and Development OECD [49] in its Sustainability in Development Programs: A Compendium of Evaluation Experience 
(1989), it can be considered as "survival of projects after an initial period of investment". For this reason, it is essential to devote considerable attention to a company's preparation for change and gradually introduce the system. Only by considering the problems of a system is it possible to identify solutions. In particular, as also discussed, several researchers have pointed out critical aspects of the BSC and SBSC and research in the field $[29,30,35,50,51]$.

\subsection{Concept}

Several authors have talked about difficulties in translating strategy into action using the BSC and about how the measures might not pick up the strategic linkages of real BSC usage. Kaplan and Wisner [52] asserted that BSC measures need to be broken down into financial and nonfinancial measures in such a way that information, communication, and strategy at all levels of the organization can be aligned for effective management. During the construction of the strategic map, it is necessary to consider both short-term and long-term vision goals. Goals should be communicated at all levels inside the organization. Nørreklit $[52,53]$ was highly critical of claims of causal relationships between the four perspectives of the BSC and of the validity of the system to serve as a strategic management tool. She argued that the BSC had problems with some of its key assumptions and relationships, and that there was not a causal but rather a logical relationship among the areas it covers. Further, Nørreklit [53] noted that the BSC was not the valid strategic management tool that Kaplan and Norton [54] claimed it was, because it had difficulty ensuring organizational and socio-environmental rooting.

\subsection{Structure}

Many problems have been highlighted in the literature regarding the structure of the tool in its implementation process. First, the BSC is considered a tool that is too expensive, and this represents a considerable barrier for firms that want to implement it. Consequently, implementation and construction of this strategic tool are difficult, and it represents a solution for only a few large companies. Moreover, outputs are not clear and the number of indicators is too limited because of the difficulty in translating, in quantitative terms, the results obtained. Therefore, there is some difficulty in understanding the most important criteria that are adaptable to evaluate the overall performance. This cluster also includes the limits connected to the target/objective, which were fixed in the construction of the strategic map. The goals are not clearly defined in the strategic map and are not shared among all corporate levels inside the organization. During construction of the strategic map, it is necessary to consider both short-term and long-term vision goals. These should be communicated at all levels inside the organization. Furthermore, it is difficult to select, fix, and then communicate the objectives to be achieved. In fact, the lack of a link between managers and goals was defined during construction of the BSC. It seems doubtful that the BSC can be used effectively to translate business goals into targets for daily management [55]. In particular, there are specific barriers to effective BSC implementation that have to be overcome: visions and strategies that are not actionable; strategies that are not linked to business unit, team, and individual goals; and strategies that are not linked to longand short-term resource allocation [56].

\subsection{Environment}

Most of the authors in the literature talk about the critical aspects that hinder the success of the BSC for problems related to the consideration of qualitative analysis by managers. Scholars mainly argue for the quantitative data [57-59], and it is problematic to incorporate qualitative data into the decision-making process. It would seem that managers are too focused on the accounting dimension, so they place excessive trust in the financial indicators. This leads to wasted time and subjectivism. Lipe and Salterio's study [55] indicates that managers pay insufficient attention to leading and nonfinancial indicators, and this might limit the benefits they receive from the BSC. Moreover, most of the criticism is about the lack of integration and communication between organizational levels. Without this integration between strategic-level scorecards and the operational level, the BSC will fail. 
It will be inefficiently supported by leadership or sustained by employees. Accordingly, based on the literature, it is clear that it is difficult to improve the use of qualitative indicators in the BSC.

\subsection{Sustainability}

Sustainability issues involve all environmental (see above), social, and economic dimensions. Several authors [1,3,7-11] talk about the difficulty in aligning sustainability issues with financial outcomes and the insufficient attention paid to leading and nonfinancial indicators $[10-13,16]$. Moreover, the lack of integration between sustainability challenges and company strategy does not allow adequate consideration of these aspects in the company's goals. In addition to the enormous variety and diversity of social aspects and the lack of a common basis, it is very difficult to achieve a comprehensive classification of social aspects. In order to adapt the BSC for sustainability value creation, it is necessary to identify ways to overcome and manage these critical aspects. Accordingly, in the SBSC the alignment of sustainability issues with financial outcomes is purely instrumental. Therefore, the SBSC might at best be a useful tool for the implementation of business case strategies where firms seek to identify and leverage the potential of environmental and social management that pays off financially [60]. Moreover, SBSC systematically does not considers sustainability challenges that do not fit with a companies' strategy, irrespective of ethical considerations or the acuteness of these sustainability challenges. The usage, selection, and monitoring of the quantitative/qualitative indicators on the SBSC dimensions are not considered adequately to integrate sustainability challenges into the company strategy. Consequently, these limits can dangerously mutilate the decision-making process, and the strategies based upon it. In particular, more attention is given due to: Increasing return of investment (reduced cost of ownership linked to energy cost, over specification, consumption, and social and environmental tax) and increasing revenue (additional revenue through additional price premium brand differentiation, income from recycling/close loop programs, and sustainable innovations). In addition, several authors in the literature talk about the systematic neglect of pressing sustainability challenges that do not promise business benefits [56-58]. The lack of consideration of performing goals in terms of sustainability and the long-term objectives led to the inadequacy of the SBSC [61-63].

Another incompatibility of the SBSC with sustainability lies in its heavy reliance on alignment and linearity which is diametrically oppositional to the complex, multifaceted and ambiguous nature of sustainability challenges [16]. Hence, it neither seems wise to inflate the role of SBSC for achieving sustainability goals without considering appropriately the organizational change and stakeholders' acceptance. SBSC has to show greater structural flexibility and increased adaptability to organizational contexts.

Finally, the SBSC is inadequate to drive transformational change of business models and business strategies towards sustainability, without consider these critical aspects in the implementation process. In order to adapt the BSC for sustainability value creation, it is necessary to identify ways to overcome and manage these critical aspects.

\section{Research Methodology}

Thanks to the survey conducted with managers of Italian companies, we created a new perspective, called critical perspective, that allowed us to consider all critical aspects during the implementation and use of the SBSC, providing researchers and practitioners a way to manage critical issues connected to the BSC considering the dimensions of sustainability.

The study was drawn from two data sources, a survey and interviews.

\subsection{Survey}

Managers were contacted using the LinkedIn online platform and personal contacts. Managers were professionals who had been working on a management team for more than two years. Their ages ranged from 40 to 55 years. In the first stage of this research, a questionnaire was sent to managers in 
order to identify the knowledge, use, and limits of the SBSC based on their experience. The survey was split into two sections: the first section aims at revealing the demography; the second section was aimed for determining the information about the knowledge, use and criticism of the SBSC). In particular, the questionnaire is composed of 10 questions about: management information (age, gender, work position, working experience), knowledge of the BSC and strategic management tools, use of the SBSC and information about the criticism connected to the tool. The total sample consist of 400 Managers contacted. We received $113(28 \%)$ questionnaires completed. Out of the 113 , a total of $73(64.6 \%)$ managers used the BSC. We have based our first round of analysis on the 73 completed questionnaires. Finally, we selected 17 managers based on their experiences (more than 5 years in use of the BSC, who were working at the high organizational level) who confirmed their availability to participate in the interview face to face. The most frequent limits identified by managers were connected to the following key aspects: managers' commitment, staff training, and strategy. Table 1 shows the limits identified by managers.

Table 1. Frequency distribution of limits.

\begin{tabular}{cc}
\hline Limit & Frequency \\
\hline Top management and qualitative analysis & 11 \\
Dimension of employees & 3 \\
Strategy & 3 \\
\hline
\end{tabular}

(1) Managers and qualitative analysis

The most frequent limit was poor management commitment. This can be motivated by a lack of willingness to bring innovation into the company, because the processes that have already been adopted are considered "best practices." Managers lack confidence in the qualitative indicators and this does not allow maximum commitment to their use. The dimensions of sustainability are not integrated into the economic goals.

(2) Dimension of employees

Companies did not adequately consider stakeholders' and employees' acceptance of organizational change. They need to improve the efficacy and effectiveness of internal processes by increasing staff satisfaction. The sharing of information should be automatic in order to achieve integration of the system.

(3) Strategy

The company must have a clear strategy to follow in terms of sustainability that is shared by all operational units. The strategy must be an integral part of the BSC and must be transmitted to all company levels. Before an SBSC can be formulated, managers need to define common agreement on what the strategy is, whether it explicitly mentions sustainability or not.

\subsection{Interviews}

The aim of the interviews was to link the literature to practical points of view in order to identify ways to overcome the limits based on management experience. We selected this methodology because interviewing is a common method that researchers use to interact with and collect data from organizational participants in the field [64]. Managers can use their experience to provide ideas for future development of the tool. Once the managers confirmed their availability to participate in the interview, we introduced them to the interview through some preparatory activities. In particular, we informed them by e-mail of the main purpose of this kind of test and about what they were supposed to do. Generally, they asked for some more specific information and this was provided by holding a phone or a Skype call with them. Eventually, we arranged a meeting to run the interviews. Moreover, before running the interviews, we gathered some general information about their organizations 
(i.e., core business; target markets; number of employees) and their job (i.e., profile, role). By doing all of this, we were able to establish an easy-going contact with the interviewees and become familiar with their own working environments. Each interview lasted about $40 \mathrm{~min}$ on average (ranging from 28 to $52 \mathrm{~min}$ ) and all of them were transcribed and coded for analysis. Qualitative data were analyzed by categorizing the responses into major conceptual areas. In particular, we asked the respondents to verify the interview transcribed of the information provided and to control possible inaccuracies. In this case, we improved the validity of the process [65]. In order to improve the internal validity, we triangulated the data collected by the interviews and the secondary data. We collected and analyzed additional information as secondary data to provide a triangulation data be able to capture more relevant information in the interview process $[66,67]$. Accordingly, we supported the interview information and reduced the researcher bias. The results from all steps were then analyzed and compiled in order to finalize the critical perspective. This was done by the present authors with co-operation with company representatives.

Data were discussed through in-depth interviews (Appendix A). In particular, four meetings were necessary, each requiring four hours of discussion. They were scheduled as follows:

- Day 1: Discussion on the problems related to the tool.

Discussion about the limits identified by managers.

- Day 2: Discussion on the environmental and sustainability problems.

Analysis of the limits identified in the literature.

- Day 3: Discussion on how the SBSC's critical aspects could be overcome.

Analysis of several papers dealing with potential adaptations of the SBSC [16,59,65,68-71] and discussion about managers' solutions based on their daily experience using this tool. This provided us with possible solutions to overcome limits previously identified in the literature.

- Day 4: Creation of the critical perspective in order to manage its critical aspects (see below).

\section{Results: An Extended Framework for a Critical Review}

We used questionnaires, papers (potential adaptations), and managers' suggestions to identify ways to overcome environmental and other limits. Previous studies already attempted to identify potential solutions to overcome these limits $[7,16,35,59]$. Although these papers contribute significantly to the existing literature, they do not highlight the practical aspects closely related to the managerial practices in use that only the interviews allowed us to grasp $[64,65]$. Based on the critical aspects identified from the literature and practices, we improved the current use of the SBSC, considering the critical aspects in a new perspective called critical perspective. This perspective should be an integral part of the SBSC in order to drive it to full success by monitoring critical factors and overcoming criticism connected to the tool. We adjusted the sustainability framework, creating an Adjusted Sustainability Balanced Scorecard (ASBSC). To this end, we summarized the most relevant limits for each key assumption analyzed in the previous discussion. In particular, to achieve success of the SBSC, how will we overcome the limits associated with the tool? For each key concern, we identified the goal (control variable) that allowed us to prevent the occurrence of the limit and deviation by the given target (representing the level to achieve in order to guarantee success for the company, depending on the characteristics of the company). For each goal, we inserted the key performance indicator (KPI) to evaluate the performance goal ratio, and then considered the method to measure the KPI. For each goal, it is suitable to take into account the target representing the range of satisfaction value. In this way, we contain the SBSC's limits and this will allow the tool to be successful. The perspective is not a straitjacket for managers, but a base that needs to be developed considering the specific company's characteristics, such as other perspectives [54]. The selection of the KPI depends on the type of company and its aims. 


\subsection{Key Factors to Improve the SBSC}

The dimensions presented in Figure 1 are discussed in order to examine the conditions under which the SBSC may be effective for the survival and growth of a firm. In particular, using the critical perspective, we can identify five aspects:

- Concept

- Structure

- Environment

- Social

- Economic

\begin{tabular}{|c|c|c|c|c|}
\hline $\begin{array}{l}\text { CRITICAL } \\
\text { ASPECT }\end{array}$ & OBJECTIVES & KPI & MEASURES & TARGET \\
\hline \multirow{3}{*}{ conceptual } & $\begin{array}{c}\text { to evaluate integration between } \\
\text { levels }\end{array}$ & $\mathrm{n}$. of meetings per month & report by managers & \\
\hline & $\begin{array}{l}\text { to define performing goals in } \\
\text { terms of sustainability }\end{array}$ & $\begin{array}{l}\% \text { contribution rate of the } \\
\text { sustainability goals }\end{array}$ & $\begin{array}{l}\text { Operating profit } \\
\text { after tax - (invested } \\
\text { capital } x \text { WACC) }\end{array}$ & \\
\hline & $\begin{array}{l}\text { to define daily management's } \\
\text { goals }\end{array}$ & achieved daily goals ratio & $\begin{array}{l}\text { n. of daily goals } \\
\text { achieved } / \mathrm{n} \text { of total } \\
\text { daily goals }\end{array}$ & \\
\hline \multirow{3}{*}{ structural } & $\begin{array}{l}\text { clear definition of the } \\
\text { sustainability goals in the } \\
\text { strategic map }\end{array}$ & $\begin{array}{l}\% \text { comprehension sustainability goals } \\
\text { by the staff }\end{array}$ & questionnaire & \\
\hline & $\begin{array}{l}\text { to share sustainability goals } \\
\text { with the whole organization } \\
\text { through all corporate levels }\end{array}$ & $\begin{array}{l}\text { \% knowledge of the strategic } \\
\text { sustainability objectives by each } \\
\text { corporate unit }\end{array}$ & questionnaire & \\
\hline & $\begin{array}{l}\text { to consider both short-term and } \\
\text { long-term sustainability goals }\end{array}$ & $\begin{array}{l}\% \text { long-term sustainability objectives } \\
\text { of total sustainability objectives }\end{array}$ & $\begin{array}{l}\text { n. long-term } \\
\text { objectives/total } \\
\text { objectives }\end{array}$ & \\
\hline \multirow{3}{*}{ environmental } & $\begin{array}{l}\text { to increase the use of } \\
\text { qualitative indicators }\end{array}$ & qualitative indicator rate of use & $\begin{array}{c}\text { qualitative } \\
\text { indicators/total } \\
\text { indicators }\end{array}$ & \\
\hline & $\begin{array}{l}\text { to select most appropriate } \\
\text { sustainability indicators }\end{array}$ & $\begin{array}{l}\text { efficiency } \% \text { of sustainability } \\
\text { qualitative indicators chosen }\end{array}$ & $\begin{array}{c}\text { indicators with } \\
\text { positive correlation } \\
\text { to the } \\
\text { performance/total } \\
\text { indicators chosen }\end{array}$ & \\
\hline & $\begin{array}{l}\text { monitoring performance of } \\
\text { sustainability qualitative } \\
\text { indicators }\end{array}$ & growth rate sustainability indicator & time series & \\
\hline \multirow{3}{*}{ social } & $\begin{array}{l}\text { monitoring the sharing of } \\
\text { management decision making }\end{array}$ & $\begin{array}{l}\% \text { rate of acceptance and sharing of } \\
\text { management decision making }\end{array}$ & questionnaire & \\
\hline & $\begin{array}{c}\text { to increase stakeholders } \\
\text { acceptance of organizational } \\
\text { change }\end{array}$ & $\begin{array}{l}\% \text { rate of stakeholders acceptance of } \\
\text { organizational change }\end{array}$ & questionnaire & \\
\hline & $\begin{array}{c}\text { monitoring employees' } \\
\text { acceptance of organizational } \\
\text { change }\end{array}$ & $\begin{array}{l}\% \text { rate of employees' acceptance of } \\
\text { organizational change }\end{array}$ & questionnaire & \\
\hline \multirow{3}{*}{ economic } & $\begin{array}{c}\text { to evaluate sustainability goals } \\
\text { reached }\end{array}$ & $\begin{array}{l}\% \text { rate } n \text {. of sustainability goals } \\
\text { reached in strategic plan }\end{array}$ & $\begin{array}{l}\text { n. of sustainability } \\
\text { goals reached/ n. of } \\
\text { goals in strategic } \\
\text { plan }\end{array}$ & \\
\hline & $\begin{array}{l}\text { monitoring performance } \\
\text { sustainability indicators }\end{array}$ & growth rate indicator & time series & \\
\hline & $\begin{array}{l}\text { improving the economic } \\
\text { performance }\end{array}$ & $\%$ rate cost containment & cost analysis & \\
\hline
\end{tabular}

Figure 1. Critical dimensions.

\subsubsection{Concept}

For the first limit identified, the major criticism is essentially related to the lack of integration and communication between different organizational levels and the need to define performance goals in terms of sustainability. For the first objective, the number of meetings per month will represent the KPI. 
In order to achieve a good level of integration, the target in this case could be at least one meeting per week between all representative members of each business unit inside the organization and one meeting per week between each manager and all members of his/her business unit. The number of meetings can change according to need and the type of company. In the SBSC, integration between sustainability challenges and the company strategy is essential. All business units have to be informed about the sustainability goals defined by the management. The second goal is to define performance goals in terms of sustainability. To this end, the KPI aims to identify the goals that lead to the creation of value for the company, or indirectly contribute to the value creation (number of performance goals/number of total goals defined). The decision is made on whether sustainability goals can only be adopted during rather than before the process of formulating an SBSC. According to Figge [1], after going through the four traditional basic perspectives, it finally has to be checked whether strategically relevant environmental/sustainability or social aspects exist that significantly influence the success of the business unit's strategy. To this end, the author suggests analyzing (1) any environmental or social aspects that influence the business unit's success, (2) environmental or social aspects that represent strategic core elements at which the business unit has to excel in order to positively implement its strategy, and (3) the real contribution of the performance driver to achievement of the business unit's strategy. For the conceptual limit, the last goal focuses on the need to evaluate daily management goals. The KPI chosen is the goal achievement rate, which represents the number of daily management goals achieved. This allow managers to monitor management activity and compliance with the BSC.

\subsubsection{Structure}

The major criticism is related to correct consideration of the short- and long-term objectives and the need to clearly define sustainability goals in the strategic map. In order to overcome this kind of limit, we defined three goals to insert into the critical perspective: clearly define goals in terms of sustainability in the strategic map, share sustainability goals with all corporate levels inside the organization, and consider both short-term and long-term sustainability goals. In order to evaluate the clarity of the objectives defined, the KPI shows the rate of objective comprehension, which represents the percentage of comprehension by the staff out of the total objectives defined. Each process should be monitored and analyzed systematically using employees' just-in-time feedback. Frequent meetings with employees are necessary to discuss feedback and define an improvement strategy. An important factor is the questionnaires sent to the staff in order to obtain information to analyze (every week). The second goal aims to share strategic objectives with all corporate levels throughout the organization. The KPI is the percentage of knowledge of the strategic objectives by each corporate unit. This objective is strictly correlated with the integration between levels (see above concept). In this case, the focus is on the structure of the objectives. Questionnaires could help managers understand the level of knowledge between units inside the company. The need to consider both short-term and long-term objectives is the last aspect to consider. To this end, the KPI is the percentage of long-term objectives defined over the total objectives. In particular, it is necessary to have a balance between short- and long-term vision.

\subsubsection{Environment}

The major criticism involves the relationship between managers and qualitative analysis. We identified three main goals to consider in the critical perspective: increase the use of qualitative indicators, select qualitative indicators, and monitor the performance of the indicators chosen. This is one of the critical aspects that needs to be improved in the future to increase the performance of the BSC first, and then for the process of formulating an SBSC. For the first goal, the KPI is the qualitative indicator use ratio, which represents the percentage of qualitative indicators used over the total indicators. A good balance between qualitative and nonqualitative indicators is preferred in order to reach a high-quality level of analysis. In this context, in order to guarantee the success of the SBSC, an important aspect is the qualitative indicators, which allow relevant environmental aspects such as freedom of action, legitimacy, legality, customer satisfaction, employee satisfaction, and 
motivation and, in general, leading or lagging indicators from all other perspectives to be captured. The second goal is one of the most problematic aspects due to the difficulty in finding adequate indicators that are positive and correlate with the value of the company. We used the contribution rate of the sustainability goals. This indicator represents the profit generated in excess of cost of capital employed in order to identify the contribution of the sustainability goals. The last goal is to evaluate the performance of the indicators, monitoring the trend after the introduction of the BSC (both qualitative and nonqualitative). Therefore, more attention should be paid to the environmental aspects with regard the use, selection, and monitoring of the qualitative indicators in order to integrate sustainability challenges into the company strategy. In particular, the aspects on natural environment to consider can be summarized as follow: utility consumption (energy intensity, electricity, water, and gas consumption); emissions (to air, water, and soil); radiation, noise and vibrations; waste (the efforts to address "green-ness"); flow (effort and ability to see where your energy, water, and gas consumption flows); sources (renewable energy, renewable electric sources, sustainable water use); efficiency (monitoring).

\subsubsection{Social}

This dimension influences each member of the company. In order to ensure that the SBSC is adapted to the specific needs of the business unit chosen, is necessary to identify all strategically social relevant aspects. To this end, is essential to monitor the sharing of management decision making, along with stakeholders' (including customers, citizens, and suppliers) and employees' acceptance of organizational change. More effort should be made in monitoring this dimension, because for the great variety of social aspects it is very difficult to identify a specific set of the most relevant social issues to consider in the strategy. Zedek [72] suggests classifying social aspects not according to their contents, but according to the actors involved.

\subsubsection{Economic}

The last dimension includes evaluating the economic goals in terms of sustainability in order to control and drive the company's performance toward the achievement of making a strong contribution to sustainability and value creation. To this end, all sustainability aspects and indicators have to be directly or indirectly linked to financial performance. Is necessary to consider all financial issues presented by the investment effort in order to guarantee the achievement of sustainability goals, potential additional revenues, or cost reduction, by evaluating the sustainability goals reached, monitoring the performance of the sustainability indicators, and improving their performance. In particular, more attention is due to: Increasing return of investment (reduced cost of ownership linked to energy cost, over specification, consumption, and social and environmental tax) and increasing revenue (additional revenue through additional price premium brand differentiation, income from recycling/close loop programs, and Sustainable innovations).

The critical perspective manages and controls all other perspectives, including critical aspects, which directly or indirectly links to all goals, indicators and measures of the BSC perspectives and the sustainability dimensions. Therefore, it represents the core of the system. The traditional four perspectives and the sustainability, or nonmarket perspective are linked by cause and effect relationships based on the top down strategy from the financial perspective through the other perspectives. This hierarchical structure guarantees that all business activities are linked to the successful implementation of the business strategy. Accordingly, this approach ensures the identification of the major strategic issues of a business, as strategic core issues or performance drivers, including all sustainability dimensions in order to consider environmental, social and economic aspects in addition to the traditional dimensions of the BSC. Considering the criticism, the critical perspective makes it possible to build the ASBSC (Figure 2), integrating the BSC, critical perspective, and sustainability dimensions [1,6]. Accordingly, the process of formulating an ASBSC involves a number of basic steps. First of all, it is necessary to build the critical perspective in addition to the 
traditional perspectives, including all critical issues to manage and control it, based on the strategic goals defined, the organizational context, and the kind of company. This step is essential for both the traditional BSC and the SBSC. The second step is to identify and determine the strategic relevance of the environmental and social exposure. In the case of companies that have adopted an explicit sustainability strategy, the environmental and social aspects will play a more relevant role. In this step, is necessary to identify all environmental and social aspects that affect the business unit and that are strategically relevant. Accordingly, all objectives and KPIs have to be defined and linked toward long-term success and measured by the economic dimension. In the last step of the implementation process, sustainability data will be embedded within the four traditional perspectives or an additional nonmarket perspective $[1,18]$ in order to guarantee a balance between quantitative and qualitative indicators, which social sustainability measurement requires. There are basically three possibilities to integrate sustainability in the BSC [1].
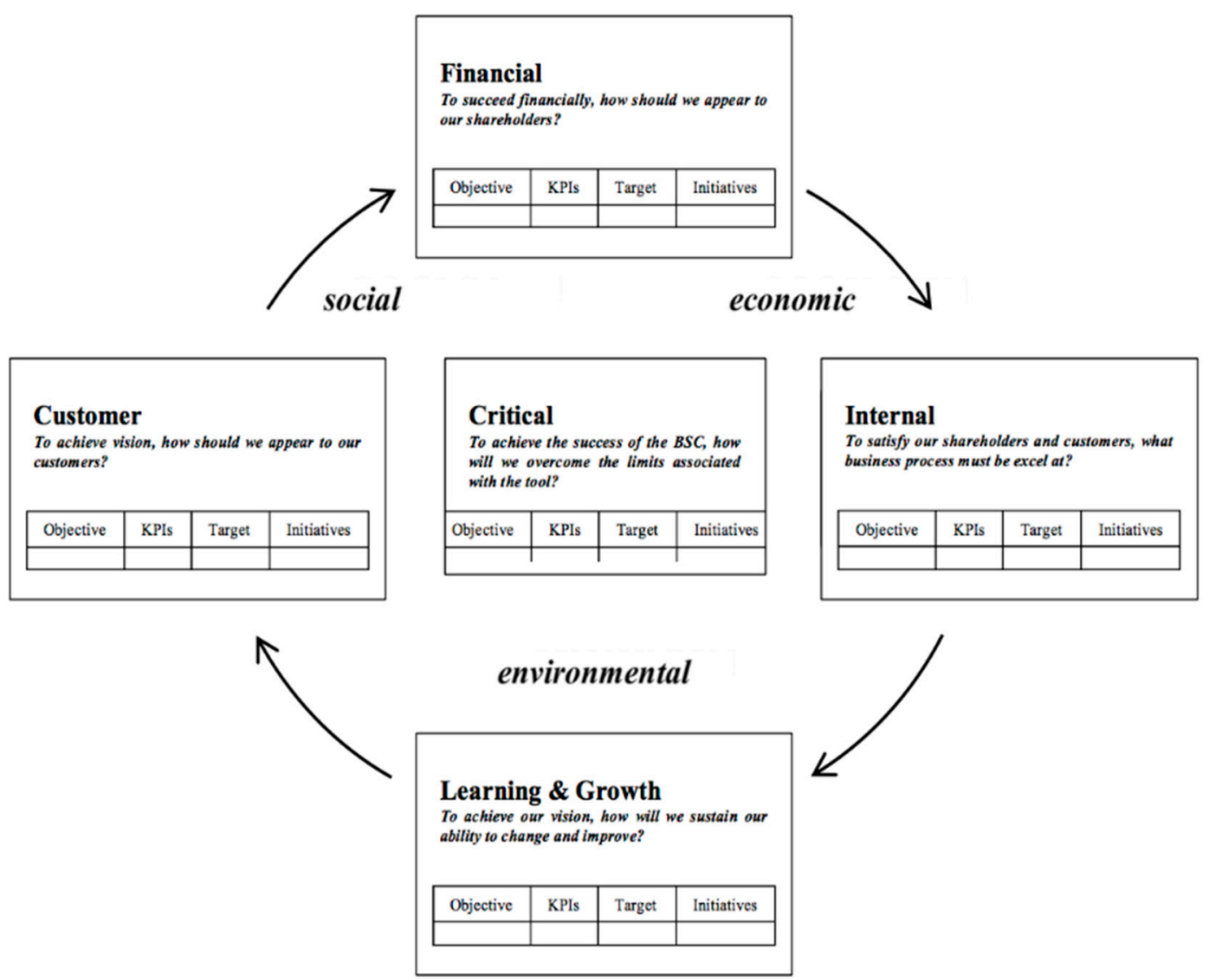

Figure 2. Adjusted Balanced Scorecard (ABSC) framework.

First, environmental and social aspects can be integrated in the existing four standard perspectives, including sustainability objectives, sustainability KPIs and sustainability measures for the Financial, Client, Internal, and Learning and Growth perspective. In this context, the Learning and Growth perspective plays a relevant role in defining sustainability objectives, sustainability KPIs, and sustainability measures.

Second, an additional perspective, named Sustainability or nonmarket perspective can be added to take environmental and social aspects into account. This perspective should include separately all sustainability dimensions in order to consider environmental, social and economic aspects in addition to the traditional dimensions of the BSC.

Lastly, a specific environmental and/or social scorecard can be formulated in addition to the BSC.

The first two variants refer to the structure of the core scorecard for a business unit. The third approach is deduced from the core scorecard and therefore representation can only be formulated in the 
second step. The selected approach depends on the nature of the strategically relevant environmental and social aspects that are identified during the process of formulating a SBSC. The choice of how environmental and social aspects are integrated is therefore taken during this process, rather than at its beginning. Accordingly, we surmise that the second approach is particularly efficient because it allows integrating and analyzing more deeply the sustainability dimensions, considering at the same time all other perspectives. This approach is more appropriate if environmental and social aspects are strategically relevant and are not already integrated in the market system. It becomes clear that for the integration of strategically relevant environmental and social aspects from outside the market system is necessary to consider an additional perspective. In order to justify an introduction of an additional nonmarket or Sustainability perspective, environmental and social aspects from outside the market system must explicitly represent strategic core aspects for the successful execution of the strategy of the company considered. Kaplan and Norton also point out that the firm-specific formulation of a BSC may involve a renaming or adding of perspective [4]. Adding a new perspective can be considered as the simplest approach for companies which want to make the sustainability as a key value of their company. The creation of value needs to consider, in addition to financial goals, the social and environmental aspects in order to improve the performance with respect to all dimensions of value creation.

\section{Discussion and Implications for Research and Practice}

The aim of this paper was to explore the status of research on the critical aspects of implementation of the SBSC with a view to identify gaps and sketch ideas for future research. The process of formulating the SBSC presented in this paper shows how the critical aspects have to be considered in the implementation process in order to support managers in managing the tool. Although past studies provide useful insights into SBSC theory and practice, we highlight some gaps in the knowledge base through the development of a new framework to implement the SBSC for sustainability value creation. The hierarchical structure and interdependence relations among the critical aspects and SBSC are inadequately addressed in the majority of studies.

Accordingly, the paper contributes to the literature considering critical issues in the first stage of the implementation of the SBSC by the critical perspective, with particular attention to the social sustainability measurement framework.

It is evident that the lack of appropriate consideration of the critical aspects identified under five different perspectives does not allow the tool to be used to its full effectiveness. Shields [73] suggests that "future research should be informed by what has been learned from past research". The SBSC can be employed effectively, but it needs to be integrated and improved concerning the concept, structure, environment, social, and economic aspects. Future implementation may lead to full effectiveness of the SBSC regarding company performance, considering the critical perspective during the implementation process.

Thanks to the contribution of the managers, we created an Adjusted Sustainability Balanced Scorecard in order to reach maximum benefit using the strategic management tool, to provide managers with a way to overcome the limits of the tool and to contribute to it success. In particular, the ASBSC allows us to consider the most relevant critical aspects that affect the performance of the SBSC. Is important to consider that the perspective is not a straitjacket for managers, but a base that needs to be developed based on a specific company's characteristics. The selection of the KPI depends on the kind of company and its strategic goals. Adding another perspective with additional KPIs could have the shortcoming of adding too much complexity to the use of the SBSC. According to managers, future research could identify other variables to insert into the perspective considering the various scenarios and contexts of a specific SBSC. One of the most important aspects is the qualitative analysis. Future research needs to consider more in-depth qualitative analysis, identify the role of qualitative indicators for the going concern, and determine the most suitable set of indicators to use that are correlated with the value of the company. 
Before formulating an SBSC, it is necessary to analyze the problems with the traditional structure of the BSC, particularly with regard to qualitative analysis. After this, an SBSC can be formulated in order to arrive at an agreement on what the strategy is, whether it explicitly mentions sustainability issues or not.

In order to ensure that the SBSC is suitable for the specific needs of the business unit chosen, the environmental and social aspects that affect the business unit must be identified. Overall, the ASBSC provides a strong tool for integrated sustainability management.

Therefore, the SBSC should be employed, but it needs to be integrated. It requires improvements to key aspects discussed above. In particular, critical perspective will encourage managers to develop and use the SBSC by monitoring critical factors and overcoming criticism connected to the tool. Moreover, future research could focus on cases of SBSC failure, reconsidering its implementation based on the ASBSC.

Researchers will continue to explore various issues around the SBSC using a range of theoretical frameworks. Qualitative indicators of CSR need to be analyzed more deeply in order to improve its current use and to capture the aspects that affect the value creation of sustainability challenges.

Finally, the research design of this study, as previously discussed, may constitute a further opportunity to improve the obtained results. Eventually, the relationships between topics reported in the model might be subject to large-scale generalizations both in the context of the BSC and for broader implications in the field of Performance Management System (PMS).

Author Contributions: Although the work is a result of a joint efforts by all authors, the paper conceptualization and methodology are due to I.H., and funding acquisition and supervision to A.C. and A.A. All authors were involved in writing the original draft, and specific sections can be attributed as follows: Section 1: I.H., A.C. and A.A.; Section 2: I.H.; Section 3: A.C.; Section 4: I.H. and A.A.; Section 5: I.H. and A.C.; Section 6: I.H. and A.C.

Funding: This research was funded by the University of Rome Tor Vergata, Department of Management and Law.

Acknowledgments: The authors would like to thank all managers for their cooperation, thoughtful support, collaboration, and valuable comments and also the University of Rome Tor Vergata, Department of Management and Law, for project funding.

Conflicts of Interest: The authors declare no conflict of interest.

\section{Appendix A}

\section{Appendix A.1. Description of Questionnaire}

The interview protocol used in this paper follows a shape, which we have molded according to the semi-structured type of interview. Accordingly, the considerations developed about how we constructed the interview questions, and how and why we assessed it, can be deemed relevant to the empirical studies. We grounded the structure of the questionnaire on a solid theoretical basis. The composition of the interview questions, in-fact, was based on the concepts and theories encapsulated within the research question. Furthermore, we paid particular attention not to influence the phrasing of the questions with an excessive use of theoretical jargon [74]. Accordingly, theory-driven words and expressions were only used as the starting point for the development of the interview protocol. In particular, we used Ferreira and Otley's [75] Performance Management Systems framework with its 12 elements. This allowed us to define the domain and coverage of the questions, namely the main issues and points that would be tackled by the questions within the interview situation.

In particular, with regards to Ferreira and Otley's (2009) Performance Management Systems (PMS) framework, we used a set of keywords picked directly from that scholarly paper published in the Management Accounting Research journal (Vision and Mission, KeySuccess Factors, Organization Structure, Strategies and Plans, Key Performance Measures, Target Setting, Performance Evaluation, Reward Systems, Information Flows, Systems and Networks, PMSs Use, PMSs Change, Strength, and Coherence). The logic that we followed was to choose what, in our opinion, were the most 
representative words for each element; hence, each element was developed into a limited number of keywords.

As a result, we would benefit from a systematic rationale to come up with a provisional set of questions (20 in total).

Appendix A.2. Questionnaire Used

\section{Discussion on the problems related to the tool}

1. Let's start by talking about the problems related to the BSC based on your experience [and let's pay attention to VISION and MISSION]

2. What do you think about the relationship between Managers, KPI and qualitative analysis?

3. What do you think about the Dimension of employees and reward system?

4. Do you know about the main strategic goals of your company?

5. Could you tell me what they are?

6. Did strategy change with respect to the past? How? And Why?

7. Accordingly, let's talk about the sustainability problems in your experience.

8. Could you tell me what are, in general, the activities or processes that you mostly control in the company?

9. What are the main success factors you leverage on, by considering them as essential to achieve those results? Could you give me an example?

\section{Discussion on the environmental and sustainability problems}

10. Well... according to the information you have just given to us, we now tackle—in more detail—about the sustainability issues.

11. What do you think about the difficult to align sustainability issues with financial outcomes and the insufficient attention to leading and non-financial indicators?

12. What do you think about the lack of integration between sustainability challenges and the strategy of the company don't allow to consider adequately these aspects in the companies' goals?

13. Managers pay insufficient attention to leading and non-financial indicators, and this might limit the benefits they receive from BSC. What do you think?

\section{Discussion on how SBSC's critical aspects could be overcome}

14. What we have been talking about so far, obviously, implies an appropriate definition of performance targets to be achieved, or at least maintained, for the activities that you directly control. Can you explain?

15. How these objectives are defined? [What are the tools (technical) which you use to define them?]

16. What are the performance measures/KPIs you leverage on/use, to this end, in your job? May you give me some example?

17. How do you know if the results generated are in line (aligned) with the strategic objectives of your company?

18. Do the performance measures that you usually use help you in this regard? How?

Creation of the critical perspective of the in order to manage its critical aspects

19. We talked about targets, KPIs and measures... Now we are going to address performance evaluation activities... To this specific end I kindly ask you to focus on the way you consider the criticism analyzed and how these affect your decision-making process.

20. For each problem identified can you provide the objective, KPI and measures to consider it during the implementation process. 


\section{References}

1. Figge, F.; Hahn, T.; Schaltegger, S.; Wagner, M. Sustainability Balanced Scorecard. Linking Sustainability Management to Business Strategy. Bus. Str. Environ. 2002, 11, 269-284. [CrossRef]

2. Pérez, C.; Monteqin, V.; Fernandez, F.; Balsera, J. Integration of Balanced Scorecard (BSC), Strategy Map, and Fuzzy Analytic Hierarchy Process (FAHP) for a Sustainability Business Framework: A Case Study of a Spanish Software Factory in the Financial Sector. Sustainability 2017, 9, 527. [CrossRef]

3. Epstein, M.J.; Wisner, P.S. Good neighbors: Implementing social and environmental strategies with the BSC. Balanced Scorec. Rep. 2001, 3, 8-11. [CrossRef]

4. $\quad$ Kaplan, R.S.; Norton, D.P. Linking the Balanced Scorecard to Strategy. Calif. Manag. Rev. 1997, 39, 53-798. [CrossRef]

5. Brown, D. Organizational Culture, 2nd ed.; Financial Times/Prentice Hall: Callaghan, Australia, $1998 ;$ p. 336.

6. Figge, F.; Hahn, T.; Schaltegger, S.; Wagner, M. The Sustainability Balanced Scorecard-A tool for value-oriented sustainability management in strategy- focused organisations. In Proceedings of the 2001 Eco-Management and Auditing Conference; ERP Environment: Shipley, UK, 2001; pp. 83-90.

7. Hansen, E.; Schaltegger, S. The sustainability balanced scorecard: A systematic review of architectures. J. Bus. Ethics 2016, 133, 193-221. [CrossRef]

8. Duman, M.; Taskaynatan, M.; Kongar, E.; Rosentrater, A. Integrating Environmental and Social Sustainability Into Performance Evaluation: A Balanced Scorecard-Based Grey-DANP Approach for the Food Industry. Front. Nutr. 2018, 5-65. [CrossRef] [PubMed]

9. Searcy, C.; Buslovich, R. Corporate perspectives on the development and use of Sustainability reports. J. Bus. Ethics 2014, 121, 149-169. [CrossRef]

10. Dias-Sardinha, I.; Reijnders, L.; Antunes, P. From environmental performance evaluation to eco-efficiency and sustainability balanced scorecards. Environ. Qual. Manag. 2002, 12, 51-64. [CrossRef]

11. Chalmeta, R.; Palomero, S. Methodological proposal for business sustainability management by means of the Balanced Scorecard. J. Operat. Res. Soc. 2011, 62, 1344-1356. [CrossRef]

12. Dias-Sardinha, I.; Reijnders, L.; Antunes, P. Developing sustainability balanced scorecards for environmental services: A study of three large Portuguese companies. Environ. Qual. Manag. 2007, 16, 13-34. [CrossRef]

13. Van der Woerd, F.; van den Brink, T. Feasibility of a responsive business scorecard: A pilot study. J. Bus. Ethics 2004, 55, 173-186. [CrossRef]

14. Elijido-Ten, E.; Tjan, Y. Sustainability Balanced Scorecard Disclosures and Corporate Commitment to Sustainability: An Australian Study. Issues Soc. Environ. Account. 2014, 8, 185-208. [CrossRef]

15. Hahn, T.; Figge, F. Why Architecture Does Not Matter: On the Fallacy of Sustainability Balanced Scorecards. J. Bus. Ethics 2018, 150, 919-935. [CrossRef]

16. Falle, S.; Rauter, R.; Engert, S.; Baumgartner, R. Sustainability Management with the Sustainability Balanced Scorecard in SMEs: Findings from an Austrian Case Study. Sustainability 2016, 8, 545. [CrossRef]

17. Searcy, C. Corporate sustainability performance measurement systems: A review and research agenda. J. Bus. Ethics 2012, 107, 239-253. [CrossRef]

18. Jassem, S.; Azmi, A.; Zakaria, Z. Impact of Sustainability Balanced Scorecard Types on Environmental Investment Decision-Making. Sustainability 2018, 10, 541. [CrossRef]

19. Alewine, H.C.; Stone, D.N. How does environmental accounting information influence attention and investment? Int. J. Account. Inf. Manag. 2013, 21, 22-52. [CrossRef]

20. Huang, T.; Pepper, M.; Bowrey, G. Implementing a Sustainability Balanced Scorecard to Contribute to the Process of Organisational Legitimacy Assessment. Australas. Account. Bus. Financ. J. 2014, 8, 15-34. [CrossRef]

21. Bieker, T.; Herbst, S.; Minte, H. Nachhaltigkeitskonzept für die Konzernforschung der Volkswagen AG. In Nachhaltig Managen mit der Balanced Scorecard. Konzept und Fallstudien; Schaltegger, S., Dyllick, T., Eds.; Gabler: Wiesbaden, Germany, 2002; pp. 315-341.

22. De Felice, F.; Petrilli, A.; Autorini, C. Development of a Framework for Sustainable Outsourcing: Analytic Balanced Scorecard Method (A-BSC). Sustainability 2015, 7, 8399-8419. [CrossRef]

23. Dias-Sardinha, I.; Reijnders, L. Evaluating environmental and social performance of large Portuguese companies: A balanced scorecard approach. Bus. Strat. Environ. 2005, 14, 73-91. [CrossRef] 
24. Moller, A.; Schaltegger, S. The sustainability balanced scorecard as a framework for eco-efficiency analyses. J. Ind. Ecol. 2005, 9, 73-83. [CrossRef]

25. Sidiropoulos, M.; Mouzakitis, Y.; Adamides, E.; Goutsos, S. Applying sustainable indicators to corporate strategy: The eco-balanced scorecard. Environ. Res. Eng. Man. 2004, 1, $28-33$.

26. Lo, S.; Sheu, H. Is corporate sustainability a value-increasing strategy for business? Corp. Gov. Int. Rev. 2007, 15, 345-358. [CrossRef]

27. Linnenluecke, M.K.; Griffiths, A. Firms and sustainability: Mapping the intellectual origins and structure of the corporate sustainability field. Glob. Environ. Chan. 2013, 23, 382-391. [CrossRef]

28. Wilson, M. Corporate sustainability: What is it and where does it come from? Ivey Bus. J. 2003, 67, 1-5.

29. Braam, G.J.M.; Nijssen, E.J. Performance effects of using the Balanced Scorecard: A note on the Dutch experience. Long Range Plan. 2004, 37, 335-349. [CrossRef]

30. Malina, M.A.; Selto, F.H. Communicating and controlling strategy: An empirical study of the effectiveness of the balanced scorecard. J. Man. Accoount. Res. 2001, 13, 47-89.

31. Barnabe, F.; Busco, C. The Causal Relationships between Performance Drivers and Outcomes: Reinforcing Balanced Scorecards' Implementation through System Dynamics Models. J. Account. Organ. Chang. 2012, 8, 528-538. [CrossRef]

32. Kraus, K.; Lind, J. The impact of the corporate balanced scorecard on corporate control—A research note. Man. Accoount. Res. 2010, 21, 265-277. [CrossRef]

33. Norreklit, H.; Norreklit, L.; Mitchell, F.; Bjomenak, T. The Rise of the Balanced Scorecard! Relevance Gained? J. Accoount. Organ. Chang. 2012, 8, 490-510. [CrossRef]

34. Malmi, T. Balanced scorecards in Finnish companies: A research note. Man. Accoount. Res. 2001, 12, $207-220$. [CrossRef]

35. Hoque, Z. 20 years of studies on the balanced scorecard: Trends, accomplishments, gaps and opportunities for future research. Br. Accoount. Rev. 2014, 46, 33-59. [CrossRef]

36. Epstein, M.J.; Wisner, P.S. Using a balanced scorecard to implement sustainability. Environ. Qual. Manag. 2001, 11, 1-10. [CrossRef]

37. Hervani, A.A.; Helms, M.M.; Sarkis, J. Performance measurement for green supply chain management. Benchmarking 2005, 12, 330-353. [CrossRef]

38. Kongar, E. Performance measurement for supply chain management and evaluation criteria determination for reverse supply chain management. In Proceedings of the International Conference on Environmentally Conscious Manufacturing, Philadelphia, PA, USA, 25-28 October 2004.

39. Tsalis, A.; Nikolaou, I.; Grigoroudis, E.; Tsagarakis, P. A framework development to evaluate the needs of SMEs in order to adopt a sustainability-balanced scorecard. J. Integr. Environ. Sci. 2013, 10, 179-197. [CrossRef]

40. Tsalis, A.; Nikolaou, E.; Grigoroudis, E.; Tsagarakis, K. A dynamic sustainability Balanced Scorecard methodology as a navigator for exploring the dynamics and complexity of corporate sustainability strategy. Civ. Eng. Environ. Syst. 2015, 32, 281-300. [CrossRef]

41. Giannoukou, I.; Beneki, C. Towards sustainability performance management system of tourism enterprises: A tourism sustainable balanced scorecard framework. Int. J. Glob. Environ. Issues 2018, 17, 175-196. [CrossRef]

42. Tsai, W.H.; Chou, W.C.; Hsu, W. The sustainability balanced scorecard as a framework for selecting socially responsible investment: An effective MCDM model. J Oper. Res Soc. 2009, 59, 1396-1410. [CrossRef]

43. Hsu, C.W.; Hu, A.H.; Chiou, C.Y.; Chen, T.C. Using the FDM and ANP to construct a sustainability balanced scorecard for the semiconductor industry. Expert Syst Appl. 2011, 38, 12891-12899. [CrossRef]

44. Van Marrewijk, M. A value based approach to organization types: Towards a coherent set of stakeholder-oriented management tools. J. Bus Ethics 2004, 55, 147-158. [CrossRef]

45. Lin, M.; Hu, J.; Tseng, M.; Chiu, A.; Lin, C. Sustainable development in technological and vocational higher education: Balanced scorecard measures with uncertainty. J. Clean. Prod. 2016, 120, 1-12. [CrossRef]

46. Nikolaou, E.; Tsalis, A. Development of a sustainable balanced scorecard framework. Ecol. Indic. 2013, 34, 76-86. [CrossRef]

47. Busco, C.; Quattrone, P. Exploring How the Balanced Scorecard Engages and Unfolds: Articulating the Visual Power of Accounting Inscriptions. Contemp. Accoount. Res. 2015, 32, 1236-1262. [CrossRef]

48. Buysse, K.; Verbeke, A. Proactive environmental strategies: A stakeholder management perspective. Strat. Manag. J. 2003, 24, 453-470. [CrossRef] 
49. Aragon-Correa, J.; Hurtado-Torres, N.; Sharma, S.; Garcia-Morales, V.J. Environmental strategy and performance in small firms: A resource-based perspective. J. Environ. Manag. 2008, 86. [CrossRef]

50. Organisation for Economic Co-Operation and Development OECD Sustainability in Development Programmes: A Compendium of Evaluation Experience; Organization for Economic Cooperation and Development Publishing (OECD): Paris, France, 1989.

51. Nørreklit, H. The balance on the balanced scorecard: A critical analysis of some of its assumptions. Man. Accoount. Res. 2000, 11, 65-88. [CrossRef]

52. Kaplan, S.E.; Wisner, P.S. The Judgmental Effects of Management Communications and a Fifth Balanced Scorecard Category on Performance Evaluation. Behav. Res. Accoount. 2009, 21, 37-56. [CrossRef]

53. Nørreklit, H. The Balanced Scorecard: What is the score? A rhetorical analysis of the Balanced Scorecard. Account. Org. Soc. 2003, 28, 591-619. [CrossRef]

54. Kaplan, R.S.; Norton, D.P. The Balanced scorecard-Measures that Drive Performance. Harvard Bus. Rev. 1992, 70, 71-79.

55. Lipe, M.G.; Salterio, S.E. The Balanced Scorecard: Judgemental Effects of common and unique performance measure. Accoount. Rev. 2000, 75, 283-298. [CrossRef]

56. Van Der Zee, J.T.M.; De Jong, B. Alignment Is Not Enough: Integrating Business and Information Technology Management with the Balanced Business Scorecard. J. Manag. Inform. Syst. 1999, 16, 137-158. [CrossRef]

57. Hutchins, M.; Sutherland, J. An Exploration of Measures of Social Sustainability and their Application to Supply Chain Decisions. J. Clean. Prod. 2008, 16, 1688-1698. [CrossRef]

58. Labuschagne, C. Assessing the Sustainability Performances of Industries. J. Clean. Prod. 2005, 13, 373-385. [CrossRef]

59. Junior, A.N.; de Oliveira, M.C.; Helleno, A.L. Sustainability evaluation model for manufacturing systems based on the correlation between triple bottom line dimensions and balanced scorecard perspectives. J. Clean. Prod. 2018, 190, 84-93. [CrossRef]

60. Gao, J.; Bansal, P. Instrumental and Integrative Logics in Business Sustainability. J. Bus Ethics 2013, 112, $241-255$. [CrossRef]

61. Margolis, J.; Walsh, J. Misery loves companies: Rethinking social initiatives by business. Adm. Sci. Q. 2003, 48, 268-305. [CrossRef]

62. Milne, J.; Kearins, K.; Walton, S. Creating adventures in wonderland: The journey metaphor and environmental sustainability. Organization 2006, 13, 801-839. [CrossRef]

63. Johanson, U.; Skoog, M.; Backlund, A.; Almqvist, R. Balancing dilemmas of the balanced scorecard. Accoount. Audit. Account. J. 2006, 19, 842-857. [CrossRef]

64. Evans, J.H.; Feng, M.; Hoffman, V.B.; Moser, D.V.; Van Der Stede, W.A. Points to consider when self-assessing your empirical accounting research. Contemp. Accoount. Res. 2015, 32, 1162-1192.

65. Bortolotti, T.; Boscari, S.; Danese, P. Succesful lean implementation: Organizational culture and soft lean practices. Int. J. Prod. Econ. 2015, 160, 182-201. [CrossRef]

66. Eisenhardt, K.; Graebner, M. Theory building from cases: Opportunities and challenges. Acad. Man. J. 2007, 50, 25-32. [CrossRef]

67. Sousa, R.; Voss, C. Contingency research in operations management practices. J. Oper. Man. 2008, 26, 697-713. [CrossRef]

68. Dalla Via, N.; Perego, P.; Van Rinsum, M. How accountability type influences information search processes and decision quality. Accoount. Org. Soc. 2018, 1-13. [CrossRef]

69. Farokhi, S.; Roghanian, E. Determining quantitative targets for performance measures in the balanced scorecard method using response surface methodology. Man. Dec. 2018, 56, 2006-2037. [CrossRef]

70. Malagueno, R.; Lopez-Valeiras, E.; Gomez-Conde, J. Balanced scorecard in SMEs: Effects on innovation and financial performance. Small Bus. Econ. 2018, 51, 221-244. [CrossRef]

71. Dai, N.T.; Free, C.; Gendron, Y. Interview-based research in accounting 2000-2014: Informal norms, translation and vibrancy. Man. Accoount. Res. 2019, 42, 26-38. [CrossRef]

72. Zedek, S. Stalking Sustainability. Green. Man. Int. 1999, 26, 1-11.

73. Shields, M. Research in Management Accounting by North Americans in the 1990s. J. Man. Accoount. Res. 1997, 9, 362. 
74. Kvale, S.; Brinkmann, S. Interviews: Learning the Craft of Qualitative Research Interviewing; Sage: Thousand Oaks, CA, USA, 2008.

75. Ferreira, A.; Otley, D. The design and use of performance management systems: An extended framework for analysis. Man. Accoount. Res. 2009, 20, 263-282. [CrossRef] 